\title{
THE EFFECTS OF PANDEMIC ERA TO TOURISM INDUSTRY IN TANGERANG
}

\author{
Listania Felia Kartika Candra ${ }^{(1)}$, Agnira Rekha ${ }^{2)}$ \\ (1) \& (2) Program Studi Pendidikan Bahasa Inggris \\ Universitas Tidar \\ listaniafeliakc@gmail.com, agnirawidiantoro@gmail.com
}

Submitted: 22 June $2020 \quad$ Revised:27 October 2020

Accepted: 28 October 2020

\begin{abstract}
The COVID-19 pandemic affected its economic impact and disrupted all the economies in the world, including in Indonesia, causing many people to lose their jobs, close some of their businesses and the possibility of an economic crisis. The monetary crisis as a result of the pandemic has an impact on the tourism industry, one of which is in Tangerang, Banten. The purpose of this paper is to provide an overall understanding of the possibility of a pandemic macroeconomic shock, which includes economic activity in several affected areas, knowing how much the hospitality industry is affected by the same experiencing losses due to not having visitors as usual days. This study uses quantitative methods with factor analysis techniques and distributes questionnaires to collect data. As a result, there are three factors that influence the tourism industry in this pandemic era, such as supporting factors, the strength factor, and the self-awareness factor. Finally, the health protocol for the New Normal transition was implemented after the dissolution of the PSBB and it is hoped that the economy can return to stability.
\end{abstract}

Keywords: Pandemic Effects, Tourism Industry, Tangerang

\section{INTRODUCTION}

Coronavirus outbreaks cause more than 200 countries in the world affected by the prolonged. Wuhan City was one of those who experienced the COVID-19 pandemic for the first time. As of March 31, 2020, there were 719,758 confirmed cases in the world. Coronavirus caused 33,673 thousand deaths due to this plague. This epidemic spread very quickly to several regions. In Indonesia, the first case was found in Jakarta, a woman and her daughter were checked by medical personnel who knew of its whereabouts. She is known to have a history of physical contact with a Japanese citizen who is familiar with this family. Another case was also found, claim 5 was a 55-year-old male. Patients are the result of further examination from Jakarta residents, precisely the same dance group cluster with cases 1, 2, 3, and others. Meanwhile, case 6 is a crew or ABK Diamond Princess. The 36-year-old male patient tested positive for the coronavirus after returning from Japan, where the cruise ship had leaned (Antara, 2020)

The number of COVID-19 patients increased dramatically in Serang District. From the beginning, only two people now increased to 5 people. The Chairperson of the Serang District COVID-19 Task Force for the Acceleration of Handling has said that three Serang District residents tested positive for COVID-19, two from Anyer Regency and one from Kopo Regency. Positive patients of 


\section{Listania Felia Kartika Candra and Agnira Rekha: The Effects of Pandemic Era to Tourism Industry in Tangerang}

COVID-19 are Anyer residents who are still 38 and 40 years old and are employees of PT IKPT, which is a project contractor of PT Chandra Asri Petrochemical. These two positive patients were hospitalized in Banten RSUD and Siloam Karawaci Hospital, Tangerang. Apart from Anyer and Kopo District, two COVID-19 patients were confirmed positive, and this elderly citizen came from Kibin District. Medical personnel have also found another case, a man who was married, after running a PCR test, he was tested positive for COVID-19. Previously, he was involved in religious activities in Jakarta. The patient was declared cured after being treated at Banten General Hospital since March 29, 2020, after receiving intensive care for 20 days, but still had to do independent isolation for 14 days at home while the family in the house was affirmed because it was directly related to the first patient, even without symptoms or the category of Orang Tanpa Gejala (Agus, 2020).

COVID-19 confirmed cases from March had entered 1,528 cases in Indonesia, 136 residents died from this disease. The government revealed that health facilities in Indonesia were not ready to handle COVID19. Careful preparation must be taken seriously at the beginning of the spread of the disease in the Republic of China (Tian et.al, 2020). At that time, it was stated that 2019nCoV would become a global epidemic. The world is increasingly wary of the arrival of this new disease. Plans for readiness from various corners of Indonesia must be carried out and prepared by ensuring the supply of medicines, Personal Protective Equipment (PPE) as well as human resources needed to deal with the global outbreak (WHO, 2020). According to the latest data from the Indonesian Ministry of Health, there are only 309,100 hospital beds in Indonesia, with the majority on the island of Java. Also, there are less than 6,000 national Intensive Care Units (ICUs). The numbers seem significant, but in reality, Indonesia only has 2.7 ICU beds per 100,000 people, and thus this country is among the lowest in Asia. Also, mechanical ventilators are not widely available in Indonesia, with rural settings, and there is a lack of protective equipment for medical personnel in hospitals. Equipment needed by hospitals such as PPE, masks, face shields, hand sanitizers, and gloves. Needs that must be needed by residents also began to decrease in number when the virus entered the territory of Indonesia. Traders start selling at prices higher than market prices. They become hoarders of masks, gloves and hand sanitizers when the world needs it. The government has implemented a PSBB (Large-Scale Social Limitation) system where all residents who do not need to leave home or go out of town, all must stay at home. For those who have emergency work to get out of the city, they must provide work permits to officers who are always patrolling in every city border. Checking body temperature, using PPE, rapid tests, and vehicle feasibility are also monitored by the police to keep the city vulnerable to the impact of the coronavirus.

The financial consequences of this pandemic are broadly called 'Coronanomics' (Barua, 2020), while some people call it 'Dark Swan' (Barua, 2020). This turmoil has resulted in the process of 'de-globalization' by forcing countries to secure the periphery, prevent the advancement of merchandise, capital and ordinary people, and the closure of business and creation in any event briefly. Countries had just begun to feel a macroeconomic blow because of the episode, and market analysts were expanding their investigations. In addition to the country that felt the blow of the economic crisis during the pandemic, many residents around Anyer felt the impact. Such as the closure of several hotels, the layoffs of hotel employees, factories, tourist attractions that are empty of visitors and access to and from the beach is very minimal. Since the first COVID-19 case was reckoned in December 2019, almost no academic research can be found on the financial aspects of the episode, while diagnostic reports are increasingly becoming pandemic. By searching the data, it can easily find out that most hotel companies that are in high demand by tourists can be 
temporarily closed due to a pandemic that has not yet ended. How hotels in Banten can survive during a pandemic and how managers respond to rethink broader decisions (decisions whether to stay open or close and how to reset prices if they remain open) and important issues are how products and service characteristics interact with the changing needs of tourists during this pandemic, whether profitable or not. How do tourists respond if many hotels and tourist attractions are forcibly closed by the government? Will there be movements between them?

First, will the pandemic cause mass closure in the hotel industry, or will most hotels remain open despite low occupancy rates? Which type of hotel is most likely to be closed, and why? Will hotel operators and customers are alert to infection points, and if many spots are infected, will they think of a better future? Secondly, discuss intensive margins for hotels that remain open. Do hotels have to reduce prices to attract consumers, and if so, how much? Are there hotels that have raised prices and if so, in what ways and why? If this pandemic continues not to stop, how long will hotel operators and consumers expect all these effects to last?

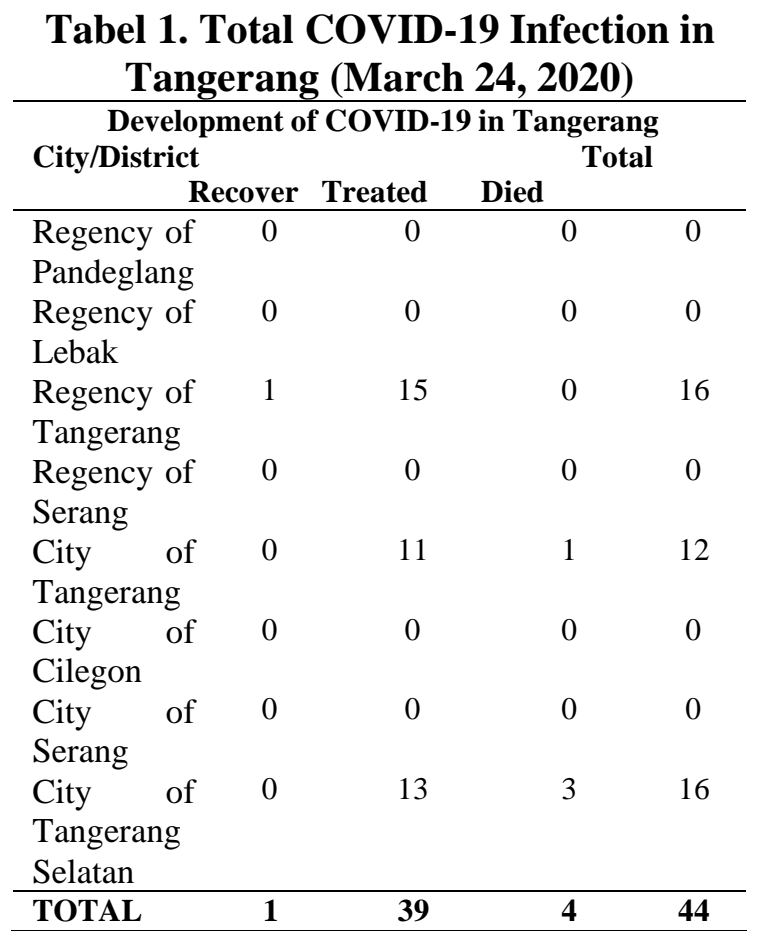

Source: infocorona.banten.go.id

JITHOR Vol 3 , No.2 April 2020 - eISSN · 2654-4687 pISSN · 2654-3894-171

\begin{tabular}{|c|c|c|c|c|}
\hline \multicolumn{5}{|c|}{$\begin{array}{c}\text { Development of COVID-19 in Banten } \\
\text { Province }\end{array}$} \\
\hline $\begin{array}{r}\text { City/District } \\
\mathbf{R}\end{array}$ & Recover & Treated & Died & Total \\
\hline $\begin{array}{l}\text { Regency of } \\
\text { Pandeglang }\end{array}$ & 5 & 2 & 3 & 10 \\
\hline $\begin{array}{l}\text { Regency of } \\
\text { Lebak }\end{array}$ & 0 & 2 & 0 & 2 \\
\hline $\begin{array}{l}\text { Regency of } \\
\text { Tangerang }\end{array}$ & 4 & 70 & 1 & 75 \\
\hline $\begin{array}{l}\text { Regency of } \\
\text { Serang }\end{array}$ & 5 & 4 & 0 & 9 \\
\hline $\begin{array}{l}\text { City of } \\
\text { Tangerang }\end{array}$ & 9 & 91 & 3 & 103 \\
\hline $\begin{array}{l}\text { City of } \\
\text { Cilegon }\end{array}$ & 0 & 2 & 0 & 2 \\
\hline $\begin{array}{l}\text { City of } \\
\text { Serang }\end{array}$ & 0 & 5 & 0 & 5 \\
\hline $\begin{array}{l}\text { City of } \\
\text { Tangerang } \\
\text { Selatan }\end{array}$ & 2 & 111 & 10 & 123 \\
\hline TOTAL & 25 & 287 & 17 & 329 \\
\hline
\end{tabular}

Source: infocorona.banten.go.id

Based on Table 1, the number of confirmed patients in Indonesia is still estimated at 44 people on March 24, 2020. While table 2 illustrates that COVID-19 patients confirmed in Indonesia as of March that the increase has identified that it is still have been put in place by the local government.

\section{LITERATURE REVIEW}

\section{Large-Scale Social Limiting Factors}

The Government of DKI Jakarta has decided to extend the period of large-scale social restrictions (PSBB) and begin to switch to a transition period until the end of June 2020. In line with this, a number of activities that were previously restricted are now loosened and can be resumed on condition that the COVID-19 health protocol is implemented. The government has made rules to remain at home or quarantine the area from mid-March.

All of these are proposed to reduce the impact of population presentations exposed to coronavirus. The government has also set a 30, 2020, has reached 329 people, meaning many Indonesians still disobey the rules that 


\section{Listania Felia Kartika Candra and Agnira Rekha: The Effects of Pandemic Era to Tourism Industry in Tangerang}

number of tourist attractions, lodging places and malls to be temporarily closed until the pandemic ends and to call for offices to implement the system Work From Home (WFH). What factors are felt by Indonesians when all activities outside the home must be done online or Work From Home:

1. Feel bored and tired when all activities must be done in the house

2. The desire to travel outside the house and feel a hangout with friends

3. Want to enjoy the hustle and bustle of a city with world noise like it used to be

4. Don't have more income because some workers are laid off from the company and can not feel alive as usual

5. Tired when everything has to be done inside the house. Reduce the ties of friendship between relatives who as usual, can chat with close range

The factors above also experienced pros and cons. Some workers who have lost their jobs have had to struggle to survive until the end of the pandemic (Nicola et.al, 2020). PSBB also caused workers such as factory employees or entrepreneurs to experience a monetary crisis due to this pandemic; most of them felt the impact was more than the profit.

It has been a month since the large-scale social publication (PSBB) was implemented in the city of Tangerang to break the Covid-19 chain. However, it is applied, the number of Covid-19 positive patients in Tangerang is still increasing rapidly. To date, a total of 269 positive cases of Covid-19 in Tangerang have spread to various regions. Of these, 132 patients were still positive. Then there were 112 patients who had been recovered, and 25 patients had died.

\section{RESEARCH METHOD}

According to Sugiyono (2014: 80), the population is a generation consisting of objects or subjects that have certain qualities and characteristics that have been determined by the author to be studied and then drawn conclusions. Factor analysis is a statistical technique mainly used to reduce or summarize data from many variables that are converted into few variables, for example from 15 old variables that are changed to 4 or 5 new variables called factors and still contain most of the information contained in the original variable. In factor analysis, there are no dependent and independent variables, processes factor analysis itself tries to find relationships (interrelationship) between a number of variables that are interdependent with others so that one or several sets of variables can be made that are fewer than the initial number.

According to WHO data, the number of infected patients in the world has reached $8,366,417$, including 450,087 deaths. Data in Indonesia to date there have been 42,762 confirmed cases of COVID-19 with 2,339 deaths. It means that the inferred data is to combine existing data and compare it. This quantitative study aims to find relationships that explain causes in measurable social facts, show variable relationships and analyze the number of infected patients in Indonesia and around the world. This is a table of the number of positive confirmed patients in Indonesia throughout the world:

\begin{tabular}{cccc}
\multicolumn{4}{c}{ Table 3. The Number of Positive } \\
Confirmed Patients \\
\hline Data & Cases & \multicolumn{1}{c}{ Died } & Total \\
\hline $\begin{array}{c}\text { World } \\
\text { (Including } \\
\text { Indonesia) }\end{array}$ & $8,366,417$ & 450,087 & $\mathbf{7 , 9 1 6 , 3 3 0}$ \\
Indonesia & 42,762 & 2,339 & $\mathbf{4 0 , 4 2 3}$ \\
\hline
\end{tabular}

Source: covid19.who.int/region/searo/country/id

According to the data that author got, the large-scale social publication (PSBB) in Tangerang was extended until the end of June 2020, and New Normal has also been officially implemented in transition by President Joko Widodo, meaning there is a high possibility that tourist attractions, hotels and malls will also be opened after the government regulation is revoked, whichever economic levels will improve and citizens must continue to maintain social distancing and obey the rules of the health protocol that has been made. 


\section{Listania Felia Kartika Candra and Agnira Rekha: The Effects of Pandemic Era to Tourism Industry in Tangerang}

The procedure is used by comparing A City with the percentage of patients infected more and B City, which has many infected patients but does not experience a very rapid surge. The Ministry of Industry is currently drafting regulations for industrial activities in the New Normal period. So far, the Ministry of Industry claims that it continues to coordinate with business actors and industry associations to formulate the policy so that it is ready for its implementation. In the formulation of the circular, the Ministry of Industry will accommodate the important points listed in the Ministry of Health Circular Number 328 of 2020 concerning Covid-19 prevention guidelines in office and industrial workplaces in supporting business sustainability in pandemic situations. From the results of coordination with domestic food and beverage industry players, they stated they were ready to operate in the New Normal era, while still observing health protocols (Rochim, 2020). To support the activities of this sector, industry players ask for support in the availability of raw materials and the smooth flow of logistics (Tri, 2020). In addition to industry readiness, projecting prices for food and beverage products will be relatively stable in the new normalcy era. The Ministry of Industry has coordinated with the Indonesian Food and Beverage Entrepreneurs Association (GAPPMI), and they are committed to maintaining price stability during the new normal. (Rochim, 2020).

Seven questions have been made and given to each group or person to fill in detail:

1. Do you feel bored when you have to work and do all the activities in the house?

2. Have you implemented the regulations that have been made by the government regarding the prohibition of gathering in a crowded place?

3. Can you get help in the form of staple food and other forms of PPE assistance?

4. Do you prefer to work from home or as usual before the virus spreads?

5. How much did you understand when the government appealed not to return to your hometown during Eid?
6. Can you explain why this virus spreads so quickly and give reasons why Indonesia has reached the highest rank in Asia?

7. Do you feel the effects of this economic crisis?

\section{RESULT AND DISCUSSION}

The results obtained from the table above are, some people only understand about the large-scale social publication (PSBB) but still violate the rules that have been made by the government, besides that, there are still many citizens who do not understand many things all are just wishful thinking when this pandemic wished to quickly finish but haven't done their best. This answer has been answered by more than 130 people. This is the data obtained from the questionnaire:

\section{Tabel 4. Table of Questionnaire}

\begin{tabular}{|c|c|c|}
\hline & Yes & No \\
\hline $\begin{array}{l}\text { Do you feel bored when you have } \\
\text { to work and do all the activities in } \\
\text { the house? }\end{array}$ & 115 & 15 \\
\hline $\begin{array}{l}\text { Have you implemented the } \\
\text { regulations that have been made by } \\
\text { the government regarding the } \\
\text { prohibition of gathering in a } \\
\text { crowded place? }\end{array}$ & 53 & 97 \\
\hline $\begin{array}{l}\text { Can you get help in the form of } \\
\text { staple food and other forms of PPE } \\
\text { assistance? }\end{array}$ & 70 & 80 \\
\hline Do you like to Work From Home? & 89 & 61 \\
\hline $\begin{array}{l}\text { How much did you understand } \\
\text { when the government appealed not } \\
\text { to return to your hometown during } \\
\text { Eid? }\end{array}$ & 120 & 30 \\
\hline $\begin{array}{l}\text { Can you explain why this virus } \\
\text { spreads so quickly and give reasons } \\
\text { why Indonesia has reached the } \\
\text { highest rank in Asia? }\end{array}$ & 112 & 38 \\
\hline $\begin{array}{l}\text { Do you feel the effects of this } \\
\text { economic crisis? }\end{array}$ & 134 & \\
\hline
\end{tabular}

Extraction Method: Google Form

Source: Google

Table 5. Gender of Respondents

\begin{tabular}{cccc}
\hline No & Variable & Gender & Sample \% \\
\hline 1 & Gender & Male & $45,7 \%$ \\
\hline 2 & Gender & Female & $104,3 \%$ \\
\hline
\end{tabular}

Based on Table 4, it is known that three new factors were formed which motivated the residents of the city of Tangerang in dealing with the impact of this pandemic. There are 


\section{Listania Felia Kartika Candra and Agnira Rekha: The Effects of Pandemic Era to Tourism Industry in Tangerang}

several factors that influence the impact of the tourism industry in Tangerang:

1. Supporting factors, this factor is very important when compared to other factors, because supporting factors will strengthen the impact caused by this virus.

2. The strength factor, the strength factor is also one that must be maintained. the strength factor is the authorities such as the police and other medical personnel who have struggled to date.

3. The self-awareness factor, this factor must also be stronger than other factors, because self-awareness is what makes the country recover faster from the suffering of this pandemic. If you have started to understand the good and bad of a pandemic, the country will recover quickly.

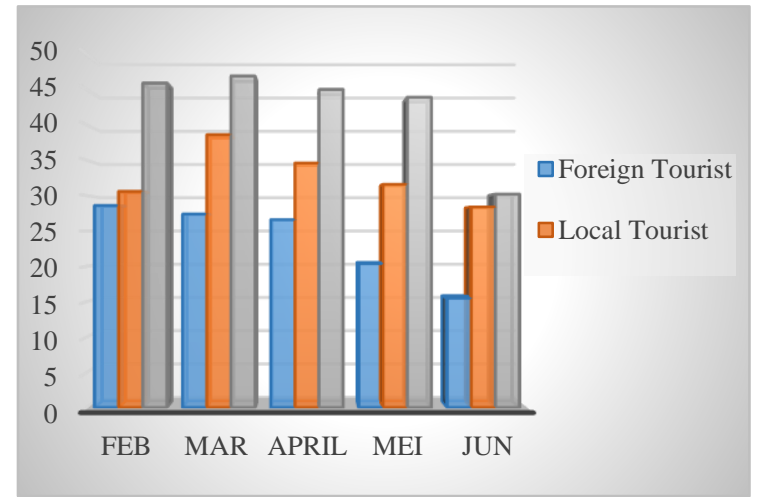

Figure 1. Diagram of Number of Tourist Visitors During COVID-19 in Tangerang

\section{CONCLUSION}

The conclusion from this article is that so many tourism industries have been affected in Banten province. Especially beach tourism, zoos and hospitality. In addition, the economic crisis also affected all industrial sectors, lack of food supplies, shortages of employee salaries during the pandemic, reduced number of hotels that were still open, more unemployment due to factories where work was laid off forever. After the implementation of PSBB in various regions, there are still many people who break the rules, do not wear masks and do not obey health protocols. Therefore, the number of patients continues to increase dramatically, especially in the district of Tangerang. The RSUD side is in short supply of PPE and space because the hospital system in Indonesia is still not ready to face this co-19. The hospital, specifically handling Covid-19 in Banten Province has also increased due to the increasing number of patients. After Banten Hospital, now Tangerang City Hospital is also used as a Covid-19 referral hospital. The determination is made through a decision letter from the Mayor of Tangerang. The Head of the Banten Health Office (Dinkes) has passed various considerations by the Tangerang City Government and finally made the Tangerang City Hospital a special referral hospital for Covid-19 (Pramudji, 2020). The determination is made through a decision letter from the local mayor. The City and Tangerang District Governments also continue to coordinate in handling this problem. They continue to provide assistance in the form of APS and other medical devices for the COVID-19 referral hospital. Before the revocation of PSBB in Banten, the manager of the hotel and tourist attractions had opened access for visitors who wanted to take a vacation. Health protocols have also been prepared from spraying disinfectants, dividing masks, dividing hand sanitizers, keeping a safe distance such as attaching an $\mathrm{X}$ sign on each chair, elevator and floor to queue which means it is prohibited to occupy the $\mathrm{X}$ sign. New normal transitions will also be implemented in Tangerang and surrounding areas from the end of June after the dismissal of the PSBB. The economy in the offer day by day is also getting better with the implementation of the PSBB. It is likely that when New Normal takes place, the economy can stabilize.

\section{REFERENCES}

Agus. (2020, Mei 7). Pasien Positif Covid-19 di Kabupaten Serang Meningkat Drastis. Retrieved from Redaksi 24: https://www.redaksi24.com/pasienpositif-covid-19-di-kabupaten-serangmeningkat-drastis/ 
Antara. (2020, 3 8). Kasus Positif Virus Corona di Indonesia Bertambah 2 Orang. Retrieved from Katadata.co.id: https://katadata.co.id/berita/2020/03/08 /kasus-positif-virus-corona-diindonesia-bertambah-2-orang

Barua, S. (2020). Understanding Coronanomics: The economic implications of the coronavirus (COVID-19) pandemic. SSRN Electronic Journal, 2.

Nicola, M., Alsafi, Z., Sohrabi, C., Kerwan, A., Al-Jabir, A., Iosifidis, C., ... \& Agha, R. (2020). The socio-economic implications of the coronavirus pandemic (COVID-19): A review. International journal of surgery (London, England), 78, 185.

Pramudji, A. (2020, April 24). Rumah Sakit Rujukan Covid-19 di Banten Bertambah. Retrieved from Kabar Banten: https://www.kabarbanten.com/rumah-sakit-rujukancovid-19-di-banten-bertambah/

Rochim. (2020, juni 3). New Normal, Kemenperin Siapkan Aturan Operasional Industri. Retrieved from Tempo.co: https://bisnis.tempo.co/read/1349196/n ew-normal-kemenperin-siapkan-aturanoperasional-industri

Sugiyono. (2014). Metode Penelitian Pendidikan Pendekatan Kuantitatif, Kualitatif, dan R\&D. Bandung: Alfabeta.

Tian, H., Liu, Y., Li, Y., Wu, C. H., Chen, B., Kraemer, M. U., ... \& Wang, B. (2020). An investigation of transmission control measures during the first 50 days of the COVID-19 epidemic in China. Science, 368(6491), 638-642.

Tri, R. (2020, Juni 3). New Normal, Kemenperin Siapkan Aturan Operasional Industri. Retrieved from Tempo.co: https://bisnis.tempo.co/read/1349196/n ew-normal-kemenperin-siapkan-aturanoperasional-industri
WHO. (2020, 03 31). Coronavirus disease (COVID-19) situation dashboard. Retrieved from World Health Organization http://www.actamedindones.org/index. php/ijim/article/download/1426/pdf 